\title{
PERAN KEPEMIMPINAN TRANSFORMASIONAL DAN MOTIVASI KERJA DALAM MEMPENGARUHI KINERJA KARYAWAN PT. XYZ
}

\author{
*Budi Satria ${ }^{1}$ \\ ${ }^{1}$ Fakultas Bisnis dan Ilmu Sosial, Program Studi Manajemen, Universitas Dian Nusantara, Jakarta, Indonesia \\ *Email Korespondensi: \\ budi.satria@undira.ac.id
}

\section{ARTIKEL INFORMASI}

Diterima:

3 March 2021

Direvisi:

15 April 2021

Dipublikasi:

16 Mei 2021

\begin{abstract}
ABSTRAK
Kinerja adalah hasil kerja secara kualitas dan kuantitas yang dicapai oleh seseorang karyawan dalam kemampuan melaksanakan tugas-tugas sesuai dengan tanggung jawab yang diberikan oleh atasan kepadanya Penelitian ini bertujuan untuk mengetahui Peran Kepemimpinan Transformasional Dan Motivasi Kerja dalam mempengaruhi Kinerja Karyawan PT. XYZ. Penelitian ini dilakukan 100 responden dengan menggunakan desktriptif kuantitatif. Karena itu analisis data yang digunakan adalah analisis statistik dalam bentuk uji regresi linear berganda. Hasil penelitian ini menunjukan Kepemimpinan Transformasional tidak berpengaruh terhadap Kinerja Karyawan, sedangkan Motivasi Kerja mampu berperang dalam mempengaruhi Kinerja Karyawan PT. XYZ.
\end{abstract}

Kata Kunci: Kepemimpinan Transformasional, Motivasi Kerja, Kinerja Karyawan

\section{PENDAHULUAN}

Dunia pada umumnya dan dunia kerja pada khususnya setelah pandemi Covid-19 akan mengalami perubahan yang drastis. Aktivitas kehidupan diperkirakan tidak akan lagi berjalan seperti sebelumnya. Akan tiba sebuah periode waktu yang dinamakan Era Normal Baru (New Normal). Ada ungkapan "You can't teach an old dog to learn new tricks", sering kali sulit membuat orang mau mencoba cara baru dalam melakukan sesuatu, terutama jika mereka telah melakukannya dengan cara-cara tertentu sejak lama. Apa mungkin anjing yang sudah tua masih bisa dan sanggup mempelajari permainan yang baru. Lalu bagaimana peran pemimpin dalam memampukan individu dan organisasi yang dipimpinnya untuk siap menghadapi dan bahkan mampu menguasai Era Normal Baru. Pada saat menerapkan perubahan pada organisasi, para pemimpin memainkan peran yang sangat penting dan strategis.

Menurut Burnes (2014), implementasi perubahan dalam skala organisasi membutuhkan pemimpin transformasional yang mampu memobilisasi pengikut untuk secara sukarela menerapkan perubahan (Hughes, Ginnet, dan Curphy 1999). Terdapat lima praktik utama seni memimpin dari seorang pemimpin transformasional menurut Kouzes dan Posner (2017). Pertama, pemimpin haruslah seorang yang menjadi panutan. Ing ngarso sung tulodo. Untuk itu pemimpin harus kredibel -dapat diandalkan dan dapat dipercaya. Pemimpin harus memiliki nilai-nilai yang jelas sebagai dasar dari setiap tindakan dan keputusannya. Nilainilai tersebut harus dikomunikasikan dengan jelas kepada anggota organisasi, tidak hanya melalui perkataan, 
tetapi terutama dalam tindakan. Walk the talk. Sehingga setiap anggota organisasi dapat melihat, mengikuti, dan menjalankan nilai-nilai tersebut secara bersama. Kedua, pemimpin harus bisa menginspirasi untuk terbentuknya visi bersama, khususnya visi pada konteks Era Normal Baru. Pemimpin harus paham betul apa yang dimaksudkan dengan Era Normal Baru. Mampu melihat adanya masa depan yang menjanjikan pada situasi yang baru tersebut. Mampu menjelaskan kepada anggota organisasi alasan perlunya berubah mengikuti Era Normal Baru, dikaitkan dengan keberlangsungan organisasi dan pemenuhan kepentingan bersama. Pemimpin harus bisa membuat seluruh anggota organisasi sepakat dan bersemangat mendukung visi bersama tersebut. Ketiga, pemimpin harus berani menantang proses, keluar dari zona nyaman dan status quo. Pemimpin secara rutin menantang tim untuk gigih mencari cara baru dan berinovasi. Pemimpin mendorong anggota organisasi untuk bereksperimen, berani mengambil risiko, dan terus belajar dari pengalaman. Keempat, pemimpin memampukan tim untuk bertindak. Pemimpin membentuk kolaborasi dengan cara membangun rasa saling percaya dan hubungan yang baik dalam tim.

Pemimpin membangun keyakinan dan kompetensi setiap anggota tim melalui pemberian kesempatan dan dukungan bagi tim dalam belajar menjalani Era Normal Baru. Pemimpin juga berempati dan mendukung secara moril terutama saat anggota organisasi menghadapi kendala atau bahkan stres dalam menjalani Era Normal Baru. Terakhir, pemimpin menyemangati jiwa dengan memberikan pengukuhan positif dalam bentuk apresiasi untuk kinerja individu dan tim, saat berhasil menjalani Era Normal Baru secara efektif yang dibuktikan dengan bertahannya atau bahkan bertumbuhnya organisasi di Era Normal Baru. Manajemen sumber daya manusia pada hakekatnya merupakan suatu upaya pengintegrasian kebutuhan personil dengan tujuan organisasi, agar idividu dapat memuaskan kebutuhannya sendiri walaupun bekerja untuk tujuan organisasi. Saat ini pengakuan terhadap manusia senantiasa mempunyai kedudukan yang semakin penting. Meskipun berada, atau sedang menuju dalam masyarakat yang berorientasi kerja. Masyarakat memandang kerja suatu yang mulai tanpa mengabaikan manusia yang melakukan pekerjaan tersebut. Manusia sebagi anggota organisasi dalam melakukan proses pekerjaan akan sangat dipengaruhi oleh kepribadian yang berbeda-beda, misalnya sifat, sikap, nilai-nilai, keinginan dan minat dan itu akan berpengaruh pada gaya kepemimpinan juga pada kinerja (Islamiyah: 2011).

Berdasarkan penelitian Sebelumnya yang dilakukan oleh Nawawi (2012) dan Marnis (2012), menunjukan bahwa kepemimpinan transformasional berpengaruh positif terhadap kinerja karyawan. pemimpin transformasional merupakan penerapan visi diikuti oleh pentingnya penerapan pemimpin yang mampu membuat perubahan disemua aspek. Model kepemimpinan transformasional mampu menyediakan solusi dalam pemahaman tentang apa yang membuat seorang pemimpin memiliki pengaruh yang besar bagi pengikutnya atau karyawan sehingga dapat menciptakan peningkatan kinerja secara berkelanjutan.

Gaya kepemimpinan transformasional merupakan gaya kepemimpinan yang menginspirasi para pengikut untuk mengesampingkan kepentingan pribadi mereka dan memliki kemampuan mempengaruhi yang luar biasa (Robbins dan Tintami,2012).

Selain itu pentingnya gaya kepemimpinan dalam organisasi, motivasi kerja juga berperan penting terhadap kualitas kinerja sumber daya manusia. Motivasi merupakan dorongan untuk mempengaruhi seseorang mencapai tujuan. Motivasi kerja bersumber dari adanya keinginan dari dalam diri untuk berkembang dan lebih maju, penghasilan atau gaji yang diterima, dan kinerja yang akan diraih.

Pencapaian prestasi karyawan yang tinggi dapat diwujudkan dengan adanya dukungan organisasi yang mampu menciptakan dan mengembangkan sumberdaya manusia. Motivasi atau dorongan untuk bekerja sangat penting dalam penentuan tinggi rendahnya kinerja perusahaan. Motivasi juga mendorong seseorang untuk bekerja lebih baik agar meraih kinerja yang diharapkan, sehingga mendapatkan apa yang menjadi kebutuhanya. Karyawan yang memiliki motivasi tinggi dan didukung oleh kepemimpinan transformasional yang baik akan menghasilkan kinerja yang tinggi pula.

Fenomena dalam penelitian ini adanya penurunan kinerja karyawan, dalam beberapa bulan, target yang ditetapkan perusahaan tidak tercapai, karena banyaknya komplain dari pengguna jasa dikarenakan kurangnya displin karyawan terhadap absensi sehingga terjadi keterlambatan, yang akhirnya menganggu aktifitas kerja, selain itu masih disebabkan faktor kepemimpinan yang masih kurang memotivasi karyawan dan belum mampu menggerakkan seluruh potensi sumber daya yang ada. Hal tersebut sering menimbulkan hal - hal yang tidak diinginkan perusahaan. Misalnya, ada barang-barang yang hilang seperti helm, kaca mobil terbuka dan lain sebagainya. Pada hakikatnya setiap karyawan mau bekerja karena suatu keinginan atas dasar motivasi. Semakin baik motivasi yang diberikan pimpinan maka semakin baik pula kinerja karyawan. 


\section{KAJIAN PUSTAKA}

\section{Gaya Kepemimpinan Transformasional Definisi Gaya Kepemimpinan Transformasional}

Rost (dalam Khoirusmadi 2010) mendefinisikan kepemimpinan sebagai sebuah hubungan saling menguntungkan diantara pemimpin dan pengikut (bawahan) menginginkan perubahan nyata mencerminkan tujuan bersama. Kepemimpinan melibatkan hubungan pengaruh mendalam, terjadi diantara orang- orang menginginkan perubahan signifikan, dan perubahan tersebut mencerminkan tujuan dimiliki bersama oleh pemimpin dan pengikutnya (bawahan). Selanjutnya Khoirusmadi menjelaskan bahwa gaya kepemimpinan merupakan pola-pola perilaku pemimpin yang digunakan untuk mempengaruhi aktivitas orang-orang yang dipimpin untuk mencapai tujuan dalam suatu situasi organisasinya yang dapat berubah. Selagi bagaimana pemimpin mengembangkan program organisasinya, menegakan disiplin yang sejalan dengan tata tertib yang telah dibuat, memperhatikan bawahannya dengan meningkatkan kesejahteraannya serta bagaimana pimpinan berkomunikasi dengan bawahannya. Pemimpin adalah orang- orang yang menentukan tujuan, dan tindakan kepada orang lain. Kepemimpinan adalah seni mempengaruhi orang atau kelompok untuk bertindak seperti yang diharapkan untuk mencapai tujuan perusahaan yang efektif dan efisien.

Menurut Burns (dalam Yukl, 2010) kepemimpinan transformasional menyerukan nilai-nilai moral dari pengikut dalam upayanya untuk meningkatkan kesadaran mereka tentang masalah etis dan untuk memobilisasi energi dan sumber daya mereka untuk mereformasi institusi. Karakteristik kepemimpinan transformasional antara lain, menanamkan kebanggaan pada diri bawahan, memperoleh dan memberikan penghormatan, menumbuhkan kepercayaan di antara bawahan, mengkomunikasikann harapan tertinggi, menggunakan simbol untuk menekankan usaha tinggi, mengeskpresikan tujuan penting dalam cara yang sederhana, menumbuhkan dan meningkatkan kecerdasan, rasionalitas dan pemecahan masalah secara hati-hati pada bawahan, memberikan perhatian secara personal, membimbing dan melayani tiap bawahan secara indivdual, serta melatih dan memerikan saran-saran.

Menurut Hughes et al. (2012) mengemukakan bahwa pemimpin transformasional memiliki visi, keahlian retorika, dan pengelolaan kesan yang baik dan menggunakannya untuk mengembangkan ikatan emosional yang kuat dengan pengikutnya. Pemimpin transformasional 28 diyakini lebih berhasil dalam mendorong perubahan organisasi karena tergugahnya emosi pengikut serta kesediaan mereka untuk bekerja mewujudkan visi sang pemimpin. Sementara itu, pemimpin transaksional tidak memiliki sifat pemimpin tadi, maupun mampu mengembangkan ikatan emosi yang kuat dengan pengikutnya ataupun menginspirasi pengikut untuk melakukan lebih dari yang mereka pikir bisa. Pemimpin transaksional diyakini memotivasi pengikut dengan cara menetapkan tujuan dan menjanjikan imbalan bagi kinerja yang baik.Menurut Artana (2012) kepemimpinan merupakan sifat, karakter atau cara seseorang dalam upaya membina dan menggerakkan seseorang atau sekelompok orang agar mereka bersedia, berkomitmen dan setia untuk melaksanakan kegiatan sesuai dengan tugas dan tanggung jawabnya untuk mewujudkan tujuan perusahaan yang telah di tetapkan sebelumnya. Dalam kepemimpinan transformasional, pemimpin memberikan inspirasi pada pengikutnya dan mempunyai dampar besar bagi perusahaan dan lingkungan sekitar perusahaan.

\section{Motivasi Kerja \\ Definisi Motivasi Kerja}

Simanjutak dan Calam (2012) menyatakan bahwa motivasi merupakan hal yang sangat penting dan harus dimulai oleh setiap orang dalam rangka meningkatkan kinerjanya, motivasi berasal dari bahasa latin movere yang berarti bergerak. Pada hakekatnya perilaku manusia dimotivasi oleh keinginan untuk mendapatkan sesuatu yang merupakan tujuan dari kegiatan. Arti dari motivasi adalah sebagai kebutuhan, keinginan, dorongan, gerak hati diri seseorang. Motivasi yang ada pada diri seseorang akan mewujudkan suatu perilaku yang diarahkan pada tujuan mencapai sasaran kepuasan. Dapat disimpulkan bahwa motivasi adalah semangat atau dorongan dalam diri seseorang untuk melakukan kegiatan tertentu guna mencapai suatu tujuan yang dapat berpengaruh positif terhadap kinerja.

Sunyoto (2012) menyatakan bahwa motivasi menjadi penting karena dengan motivasi diharapkan setiap karyawan mau bekerja keras dan antusias untuk mencapai kinerja yang tinggi. Perilaku seseorang dipengaruhi dan dirangsang oleh keinginan, pemenuhan kebutuhan serta tujuan dan kepuasannya. Rangsangan ini akan menciptakan dorongan pada seseorang untuk melakukan aktifitas. Motivasi juga dapat di nilai sebagai suatu daya dorong ( driving force ) yang menyebabkan orang dapat berbuat sesuatu untuk mencapai tujuan. Dalam hal ini, motivasi menunjuk pada gejala yang melibatkan dorongan perbuatan terhadap tujuan tertentu. Jadi, motivasi dalam hal ini sebenarnya merupakan respons dari suatu aksi, yaitu tujuan. Motivasi 
memang muncul dari dalam diri manusia, tetapi kemunculanya karena rangsangan atau dorongan oleh adanya unsur lain, dalam hal ini adalah tujuan. Tujuan ini menyangkut soal kebutuhan ( Uno, 2012).

Menurut Robbins dalam Mamik (2010) bahwa motivasi kerja merupakan suatu dorongan yang membuat seseorang bertindak atau berperilaku dengan kemungkinan terpenuhinya tujuan atau kebutuhan pribadi dalam bekerja. Selanjutnya menurut Gibson, et.al (2010), "Motivation has to do with artinya Motivasi berhubungan dengan (1) the direction of behaviour artinya arah perilaku (2) the strength of response (i.e effort) once an employee choose to follow a course of action, and artinya kekuatan reaksi setelah karyawan memilih untuk melakukan seperangkat tindakan, dan (3) persistence of the behaviour or how long the person continues to behave in a particular manner artinya ketetapan perilaku atau seberapa lama seseorang terus menerus berperilaku dalam sikap tertentu.

Frederick Herzberg memilah hirarki kebutuhan maslow menjadi kebutuhan tingkat rendah (fisiologis, rasa aman, dan sosial) dan kebutuhan tingkat tinggi (ego dan perwujudan diri) dan mengemukakan bahwa cara terbaik untuk 31 memotivasi seseorang adalah dengan memenuhi kebutuhan tingkat tingginya. Herzberg mengatakan bahwa memberikan seseorang kenaikan gaji atau kondisi kerja yang lebih baik tidaklah dapat memotivasinya karena kebutuhan tingkat rendah dapat terpenuhi dengan cepat. Dan apabila terpenuhi (misalnya, apabila seseorang telah memiliki penghasilan cukup) maka satu-satunya cara untuk memotivasi orang itu adalah dengan ,menawarkan uang lebih banyak atau bahkan kondisi kerja yang lebih baik dalam proses peningkatan kualitas diri. Cara yang tepat untuk memotivasi menurut Herzberg adalah mengatur pekerjaan sedemikian rupa sehingga orang itu memperoleh rasa keberhasilan dengan melakukan pekerjaan itu. Selanjutnya, dengan melaksanakan pekerjaan itu orang tersebut termotivasi untuk terus berusaha memenuhi kebutuhannya tanpa batas dalam rangka upaya pemuasan kebutuhan tingkat yang lebih tinggi seperti keberhasilan dan pengakuan (Desler, 2010) .

\section{Kinerja Karyawan \\ Definisi Kinerja Karyawan}

Kinerja adalah hasil kerja secara kualitas dan kuantitas yang dicapai oleh seseorang karyawan dalam kemampuan melaksanakan tugas-tugas sesuai dengan tanggung jawab yang diberikan oleh atasan kepadanya. Selain itu, kinerja juga dapat diartikan sebagai suatu hasil dan usaha seseorang yang dicapai dengan adanya kemampuan dan perbuatan dalam situasi tertentu. Berikut ini adalah definisi kinerja karyawan menurut para ahli. Menurut Anwar Prabu Mangkunegara (2014:9) Kinerja Karyawan adalah hasil kerja secara kualitas dan kuantitas yang dicapai oleh seseorang karyawan dalam melaksanakan tugasnya sesuai dengan tanggung jawab yang diberikan kepadanya. Selanjutnya, definesi menurut Hasibuan (2003:93) Kinerja karyawan merupakan suatu hasil kerja yang dicapai seseorang dalam melaksanakan tugas-tugas yang dibebankan kepadanya yang didasarkan atas kecakapan, pengalaman dan kesungguhan serta waktu. Dengan kata lain bahwa kinerja adalah hasil kerja yang dicapai seseorang dalam melaksanakan tugas yang diberikan kepadanya sesuai dengan criteria yang ditetapkan. Menurut Rivai (2011:554) menyatakan Kinerja karyawan merupakan perilaku nyata yang ditampilkan setiap orang sebagai prestasi kerja yang dihasilkan oleh karyawan sesuai dengan perannya dalam perusahaan. Berdasarkan definisi dari para ahli diatas maka dapat dikatakan bahwa kinerja karyawan adalah hasil kerja secara kualitas dan kuantitas yang dicapai oleh seseorang karyawan dalam melaksanakan tugas yang dibebankan kepadanya sesuai dengan perannya dalam perusahaan.

\section{Pengaruh Gaya Kepemimpinan Transformasional dengan Kinerja Karyawan}

Fungsi kepemimpinan yang paling penting adalah memberikan contoh kepada bawahannya agar mencapai kinerja yang maksimal. Kepemimpinan transformasional diyakini memiliki pengaruh terhadap perusahaan bentuk non keuangan seperti kepuasan kerja dan kinerja karyawan. Pemimpin transformasional memotivasi pengikutnya untuk melakukan kinerja diluar dugaan (beyond normal expectation) melalui transformasi pemikiran dan sikap mereka untuk mencapai kinerja diluar dugaan tersebut (Simanjuntak dan Calam, 2012).

Italiani (2013) dalam penelitiannya menyimpulkan bahwa kepemimpinan transformasional berpengaruh secara positif terhadap kinerja. Di penelitian yang lain dilakukan oleh Maulizar, dkk (2012) bahwa kepemimpinan transformasional memiliki pengaruh yang signifikan terhadap kinerja karyawan. Dari beberapa penelitian diatas dapat disimpulkan bahwa ada hubungan antara kepemimpinan transformasional terhadap kinerja karyawan.

$\mathrm{H}_{1}$ : Gaya kepemimpinan transformasional berpengaruh positif terhadap kinerja karyawan. 


\section{Pengaruh Motivasi Kerja dengan Kinerja Karyawan}

Motivasi merupakan masalah yang kompleks dalam organisasi, karena setiap kebutuhan da keinginan tiap individu berbeda. Seseorang yang termotivasi tinggi akan menyelesaikan semua tugas yang diberikan kepadanya. Dalam teori Abraham Maslow dinyatakan bahwa kebutuhan manusia terdapat lima tingkatan yaitu kebutuhan fisiologis, kebutuhan akan rasa aman, kebutuhan sosial, kebutuhan penghargaan dan kebutuhan aktualisasi diri. Menurut Maslow bila kebutuhan tingkatan pertama terpenuhi, kebutuhan tingkat berikutnya akan menjadi dominan. Manusia akan didorong untuk memenuhi kebutuhan yang paling kuat sesuai waktu, keadaan dan pengalaman yang bersangkutan mengikuti suatu hirarki. Proses diatas menunjukkan bahwa kebutuhan-kebutuhan seperti target dan saling menopang. Kebutuhan yang telah terpuaskan akan berhenti menjadi motivasi utama dari perilaku (Harsuko,2011).

Faktor motivasi memiliki hubungan langsung dengan kinerja karyawan. Sesuai dengan pendapat David Mc. Clelland yang mengatakan bahwa motivasi kerja karyawan akan timbul bila ada pemusaan kebutuhan, yaitu: kebutuhan untuk prestasi, kebutuhan akan kekuasaan dan kebutuhan akan berafiliasi. Dengan terpenuhi kebutuhan tersebut akan meningkat kinerja karyawan. Semakin tinggi motivasi karyawan akan semakin tinggi pula kinerja karyawan. Semakin tinggi tingkat intensitas kerjanya,semakin karyawan memahami tujuan organisasi dan semakin tekun kerjanya maka motivasi karyawan semakin tinggi.

Dari penjelasan diatas dapat disimpulkan bahwa motivasi dari kinerja sangatlah berkaitan. Semakin tinggi motivasi yang diberikan,maka semakin tinggi pula kinerja karyawan. Hubungan antara motivasi dan kinerja berbanding lurus,artinya bahwa semakin tinggi motivasi karyawan dalam bekerja maka kinerja yang dihasilkan juga tinggi. Begitu juga sebaliknya ketika motivasi karyawan semakin rendah dalam bekerja maka kinerja yang dihasilkan akan semakin rendah dan kurang optimal. Sedangkan karyawan dapat bekerja dengan baik bila memiliki kinerja yang tinggi sehingga dapat menghasilkan kerja yang baik pula.

$\mathrm{H}_{2}$ : Motivasi kerja berpengaruh positif terhadap kinerja karyawan.

\section{Kerangka Pemikiran}

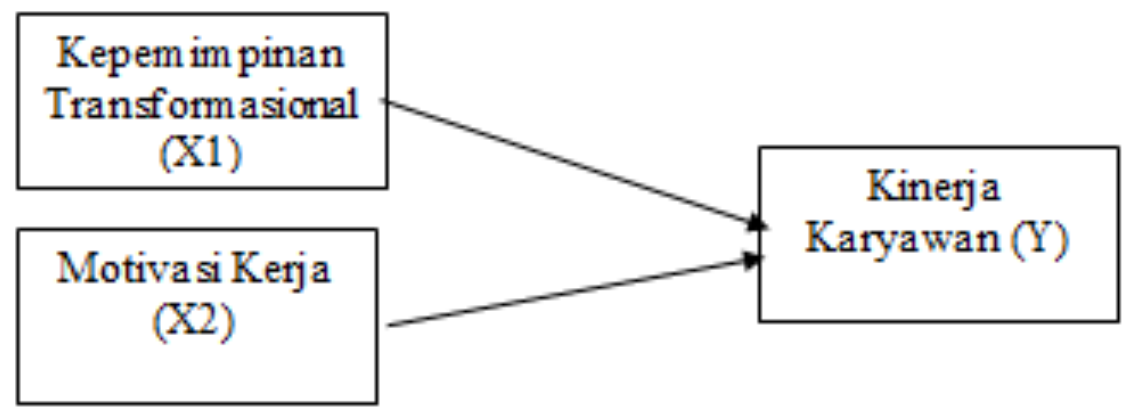

Gambar 1. Rerangka Konseptual

\section{METODE}

Penelitian ini dilakukan di PT. XYZ. Pelaksanaan penelitian ini dilakukan dari bulan Juni sampai Agustus 2020. Penelitian ini dilakukan untuk mengetahui perang kepemimpinan transformasional dan motivasi kerja dalam mempengaruhi kinerja karyawan PT. XYZ. Populasi dalam penelitian ini adalah karyawan PT. XYZ yang berjumlah 100 orang.

\section{HASIL DAN PEMBAHASAN}

\section{Hasil Uji Regresi Linier Berganda}

Tabel 1. Hasil Uji Regresi Linier Berganda

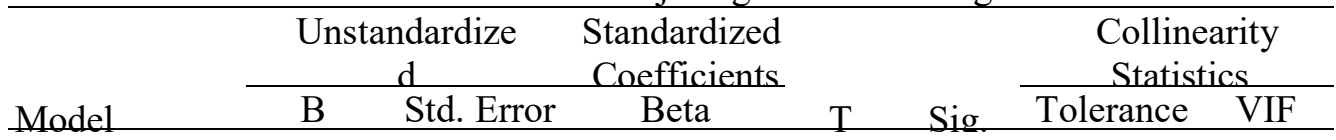


JBEMK | Volume 1, Issue 1 (2021) | 27-35

\begin{tabular}{llrrrrrrr}
\hline 1 & (Constant) & 2.206 & .653 & & 3.376 & .001 & & \\
\cline { 2 - 9 } & & .077 & .159 & .063 & .487 & .628 & .884 & 1.131 \\
\cline { 2 - 9 } & $\mathrm{GK}$ & .347 & .133 & .337 & 2.615 & .011 & .884 & 1.131 \\
\hline
\end{tabular}

a. Dependent Variable: KK

Sumber: Hasil pengolahan data SPSS 23

Berdasarkan hasil olah data dengan menggunakan SPSS pada tabel diatas dapat diperoleh rumusan persamaan regresi linier berganda untuk variabel independen (Gaya kepemimpinan transformasional dan Motivasi kerja) terhadap variabel dependen (Kinerja karyawan) sebagai berikut :

$\mathbf{Y}=\mathbf{a}+\mathbf{b} 1 \mathbf{X} 1+\mathbf{b} 2 \mathbf{X} 2+\mathbf{e}$

$\mathrm{Y}=2,206+0,077 \mathrm{X} 1+0,347 \mathrm{X} 2+\mathrm{e}$

Dari persamaan matematis regresi linier berganda tersebut dapat disimpulkan sebagai berikut:

1) Konstanta sebesar 2,206. Yang berarti jika variabel gaya kepemimpinan transformasional dan motivasi kerja sama dengan nol, maka variabel kinerja karyawan sebesar 2,206.

2) Koefisien $X_{1}$ sebesar 0,077. Yang berarti jika variabel gaya kepemimpinan transformasional mengalami peningkatan dan variable lainnya tetap, maka akan menyebabkan peningkatan kinerja sebesar nilai regresinya.

3) Koefisien $\mathrm{X}_{2}$ sebesar 0,347. Yang berarti jika variabel motivasi kerja mengalami peningkatan dan variable lainnya tetap, maka akan menyebabkan peningkatan kinerja sebesar nilai regresinya.

\section{Hasil Uji Hipotesis}

\section{Uji Koefisien Determinasi $\left(\mathbf{R}^{2}\right)$}

Koefisien determinasi ini digunakan untuk mengatahui seberapa besar variabel-variabel bebas memiliki pengaruh terhadap variabel terikatnya. Nilai koefisien determinasi digunakan adjusted $\mathrm{R}$ square. Dapat dilihat pada tabel berikut ini:

Tabel 2. Hasil Uji Koefisien Determinasi (R2)

\begin{tabular}{|c|c|r|c|r|r|}
\hline \multicolumn{7}{|c|}{ Model Summary } \\
\hline Model & R & R Square & $\begin{array}{c}\text { Adjusted R } \\
\text { Square }\end{array}$ & $\begin{array}{c}\text { Std. Error of the } \\
\text { Estimate }\end{array}$ & Durbin-Watson \\
\hline 1 & $.744^{\mathrm{a}}$ & .863 & .103 & .43122 & 1.852 \\
\hline
\end{tabular}

a. Predictors: (Constant), M, GK

b. Dependent Variable: KK

Sumber: Hasil pengolahan data SPSS 23

Berdasarkan tabel 2 diketahui hasil koefisien determinasi (adjusted $\mathrm{R}^{2}$ ) sebesar 0,103 yang artinya $10,3 \%$ yang berarti kontribusi Kinerja Karyawan dapat dijelaskan oleh ketiga variabel independen yaitu Gaya Kepemimpinan Transformasional Dan Motivasai Kerja. Jadi selebihnya sebesar 89,7\% dijelaskan oleh variabele-variabel lain yang tidak diteliti dalam penelitian ini.

\section{Uji Ketepatan Model (Uji Statistik F)}

Uji statistik $F$ menunjukkan apakah variabel independen yang dimaksud dalam model mempunyai pengaruh secara bersama-sama terhadap variabel dependennya. Hasil pengujian statistik F dapat dilihat pada tabel 3 berikut:

Tabel 3. Hasil Uji F

\begin{tabular}{|c|c|c|c|c|c|}
\hline Model & $\begin{array}{l}\text { Sum of } \\
\text { Sauares }\end{array}$ & $D f$ & Mean Sauare & $\mathrm{F}$ & Sig \\
\hline 1 & 1.669 & 2 & .835 & 4.488 & $015 \mathrm{~b}$ \\
\hline \multirow{2}{*}{$\begin{array}{l}\text { Regression } \\
\text { Residual }\end{array}$} & 10.971 & 59 & .186 & & \\
\hline & 12.640 & 61 & & & \\
\hline
\end{tabular}

a. Dependent Variable: KK

b. Predictors: (Constant), M, GK

Sumber : Hasil olah data SPSS 23 
Berdasarkan Tabel 3 dapat dilihat nilai probabilitas sig 0,000 itu berarti nilai probabilitas lebih kecil dari 0,05 maka model diterima, sehingga dapat disimpulkan bahwa gaya kepemimpinan transformasional dan motivasi kerja secara bersama-sama berpengaruh terhadap kinerja karyawan.

\section{Uji Ketepatan Signifikansi Parsial (Uji T)}

Uji Statistik t pada dasarnya menunjukkan seberapa jauh pengaruh satu variabel penjelas atau independen secara individual dalam menerangkan variasi variabel dependen. Pengambilan keputusan dapat dilakukan dengan melihat probabilitas. Jika probabilitas/signifikansi $>0,05$ maka Ho diterima dan Ha ditolak dan jika probabilitas/signifikansi $<0,05$ maka Ho ditolak dan Ha diterima.

Tabel 4. Hasil Uji t

\begin{tabular}{|c|c|c|c|c|c|c|c|}
\hline \multirow[b]{3}{*}{$\begin{array}{l}\text { Model } \\
\text { (Constant) }\end{array}$} & \multirow{2}{*}{\multicolumn{2}{|c|}{$\begin{array}{r}\begin{array}{c}\text { Unstandardized } \\
\text { Coefficients }\end{array} \\
\text { Std. B }\end{array}$}} & \multirow{2}{*}{$\begin{array}{l}\text { Standardized } \\
\text { Coefficients }\end{array}$} & \multicolumn{4}{|c|}{$\begin{array}{l}\text { Collinearity } \\
\text { Statistics }\end{array}$} \\
\hline & & & & & & & \\
\hline & $\begin{array}{l}\text { Frror } \\
2.206\end{array}$ & .653 & Beta & $\frac{t}{3.3}$ & $\begin{array}{l}\text { Sig } \\
.001\end{array}$ & Tolerance & VIF \\
\hline GK & .077 & .159 & .063 & .4 & .628 & .884 & \\
\hline $\mathrm{M}$ & .347 & .133 & .337 & 2.6 & .011 & .884 & \\
\hline
\end{tabular}

Dari tabel diatas dapat ditarik kesimpulan sebagai berikut:

a. Uji Hipotesis Gaya Kepemimpinan Transformasional Terhadap Kinerja Karyawan

Berdasarkan tabel 4.20 probabilitas sig gaya kepemimpinan transformasional sebesar 0,628 lebih besar dari 0,05, sehingga Ho diterima dan Ha ditolak, maka dapat dinyatakan secara parsial gaya kepemimpinan transformasional $\left(\mathrm{X}_{1}\right)$ berpengaruh signifikan terhadap kinerja karyawan $(\mathrm{Y})$.

b. Uji Hipotesis Motivasi Kerja Terhadap Kinerja Karyawan

Berdasarkan tabel 4.20 probabilitas sig motivasi kerja sebesar 0,011 lebih kecil dari 0,05,sehingga Ho ditolak dan $\mathrm{Ha}$ diterima, maka dapat dinyatakan secara parsial motivasi kerja $\left(\mathrm{X}_{2}\right)$ berpengaruh signifikan terhadap kinerja karyawan (Y).

\section{Pembahasan Hasil Penelitian \\ Peran Kepemimpinan Transformasional da lam me mpengaruh i Kinerja Karyawan}

Berdasarkan hasil perhitungan uji $t$ menunjukkan hasil nilai t hitung sebesar 0,47 dan nilai signifikan sebesar 0,628 lebih besar dari 0,05. Hal ini menunjukkan prinsip-prinsip gaya kepemimpinan transformasional seperti, simplikasi, motivasi, fasilitas, inovasi, mobilitas, siap siaga dan tekad, belum bisa terimplementasi dengan baik kepada karyawan di PT. XYZ. walaupun tidak signifikan dapat menurunkan kinerja karyawan namun, hal ini menunjukkan perlu adanya perbaikan gaya kepemimpinan transformasional di PT. XYZ. Hal ini sesuai dengan hasil penelitian yang dilakukan oleh Surbakti (2013), dan Abdilah (2011) dalam penelitiannya menyimpulkan bahwa kepemimpinan transformasional berpengaruh secara positif terhadap kinerja karyawan.

\section{Peran Motivasi Kerja dalam mempengaruhi Kinerja Karyawan}

Berdasarkan hasil perhitungan uji t menunjukkan hasil nilai $t$ hitung sebesar 2,615 dan nilai signifikansi sebesar 0,011 lebih kecil dari 0,05. Sehingga dapat disimpulkan bahwa variabel motivasi berpengaruh signifikan terhadap Kinerja Karyawan. Hal ini hipotesis ini didukung oleh penelitian yang dilakukan oleh Mamik (2010) dengan hasil penelitian menunjukkan bahwa ada pengaruh baik secara simultan maupun parsial antara variabel gaya kepemimpinan transformasional dan motivasi kerja terhadap kinerja karyawan. Sesuatu yang dikerjakan karena ada motivasi akan membuat orang senang, bergairah dan bersemangat mengerjakannya. Selain itu, karyawan juga merasa dihargai atau diakui pekerjaannya. sehingga mau bekerja keras, sehingga berdampak pada peningkatan pekerjaannya. Wayan Supartha, I Gede Riana (2014) dimana motivasi kerja berpengaruh positif dan signifikan terhadap kinerja karyawan.

\section{KESIMPLAN DAN SARAN}




\section{Kesimpulan}

Berdasarkan hasil penelitian dan pembahasan pada bab-bab sebelumnya mengenai peran kepemimpinan transformasional dan motivasi kerja dalam mempengaruhi kinerja karyawan pada PT. XYZ, maka kesimpulan dalam penelitian ini sebagai berikut:

a. Kepemimpinan transformasional tidak mampu memberikan pengaruh kepada kinerja karyawan PT. XYZ. Yang berarti peningkatan atau penurunan kepemimpinan transformasional tidak akan merubah kinerja karyawan.

b. Motivasi memberikan pengaruh positif dan signifikan kepada kinerja.

c. karyawan pada PT. XYZ. Yang berarti jika motivasi karyawan mengalami peningkatan maka kinerja karyawan akan meningkat.

\section{Saran}

Berdasarkan hasil kesimpulan diatas, maka dapat diberikan saran-saran sebagai berikut:

a. Bagi PT. XYZ

a) Kepemimpinan Transformasional yang diberikan kepada karyawan harus lebih intensif dan efektif, sehingga karyawan bisa merasakan metode kepemimpinan transformasional yang diterapkan oleh perusahaan.

b) Motivasi yang telah diterapkan PT XYZ cukup akan menjadikan seseorang karyawan lebih semangat bekerja yang akhirnya akan menciptakan kinerja karyawan yang semakin meningkat.

b. Bagi Penelitian Selanjutnya

Bagi peneliti berikutnya, gunakan variable lainnya seperti disiplin, pengembangan sdm dan lainlain.

\section{REFERENCES}

Arifin, Z. 2011. Penelitian Pendidikan: Metode dan Paradigma Baru. Remaja Rosdakarya. Bandung

Artana, I Wayan Arta. (2012). Pengaruh Kepemimpinan, Kompensasi, dan Lingkungan Kerja Terhadap Kinerja Karyawan Studi Kasus di Maya Ubud Resort \& Spa. Jurnal Manajemen, Strategi Bisnis, dan Kewirausahaan, Vol. 2, No. 1

Ben, Etim Edoh, Agu .O. Agu, 2012. Impact of Transformational and Transactional Leadership on organizational performance. International journal for current research. 4(11).

Desler, Gary. 2010. Manajemen Personalia Teknik dan Konsep Modern. Jakarta : Erlangga

Fatchur, R., Armanu, dan Novita, M.2011. Pengaruh Pemberdayaan Psikologis dan Komitmen Afektif terhadap Kepuasan Kerja dan Kinerja Pegaawai (Studi pada Dinas Tata Kota dan Pengawasan Bangunan Kota Mataram). Jurnal Aplikasi Manajemen. Vol. 10. No.1. ISSN: 1693

Ghozali, Imam. (2011). Aplikasi Analisis Multivariate dengan Program IBM SPSS 19. Semarang : Badan Penerbit Universitas Diponegoro

Ghozali, Imam. 2013. Aplikasi Analisis Multivariate Dengan Program SPSS, Edisi Tujuh. BP Universitas Diponegoro. Semarang.

Gomes, Faustino Cardoso. 2001. Manajemen Sumber Daya Manusia, Yogyakarta: Penerbit Andi Offset.

Islamiyah, , Nurul, 2011. Skripsi "Pengaruh Gaya Kepemimpinan Partisipatif dan Lingkungan Kerja Terhadap Kinerja Karyawan Pada Dinas Sosial, Tenaga Kerja dan Transmigrasi di Kabupaten Bangkalan" . Surabaya: UNTAG Surabaya.

Hasibuan, Malayu. (2010). Manajemen Sumber Daya Manusia, edisi revisi, Jakarta: Bumi Aksara

Handoko, T. Hani. 2011. Manajemen, Yogyakarta BPFE-Yogyakarta

Hami, Sanusi (2014) Manajemen Sumber Daya Manusia Lanjutan, Yogyakarta: Deepublish

Indrayanto, A., John, B., Kandy, B., dan Noermijati 2013. " A case study of transformational leadership and para-police perfomance in Indonesia". Policing : An International Journal of Police Strategies and Management. Vol.37. No 2. Pp 373-388. Emerald Insight

Khoirusmandi. 2010. "Analisis Pengaruh Kepemimpinan Transformasional terhadap Kinerja Pegawai dengan Budaya Organisasi sebagai Variabel Intervening". Pekalongan. Dalam Jurnal Manajemen Sumber Daya Manusia. 
Mondiani, Tria. 2014, Pengaruh kepemimpinan transformasional dan Kompensasi Terhadap Kinerja KaryawanPT. PLN (Persero) UPJ Semarang, Jurnal Administrasi Bisnis, Vol 1, No 1

Mangkunegara, A.A. Anwar Prabu, 2010. Evaluasi Kinerja SDM. Bandung: Reflika Aditama.

Marwansyah. 2012. Manajemen Sumber Daya Manusia. Bandung: Alfabeta

Rivai, Veithzal (2011). Manajemen Sumber Daya Untuk Perusahaan Dari Teori Ke Praktek Jakarta : Rajagrafindo Persada

Robbins, Stephen P \&Judge, Timothy A. (2013), Organizational Behavior 15 th Edition, New Jersey : Pearson Education

Rochaety, Ety. Tresnati, Ratih. Madjid Latief, Abdul 2009. "Metodologi Penelitian Bisnis: Dengan Aplikasi SPSS “. Edisi Revisi, Jakarta: Mitra Wacana Media

Sofyandi, Herman. (2008). Manajemen Sumber Daya Manusia, Edisi Pertama. Penerbit Graha Ilmu. Yogyakarta.

Sunyoto Danang. 2012. Teori, Kuesioner, dan Analisis data Sumber Daya Manusia (Praktik Penelitian). Yogyakarta : CAPS.

Suwatno dan Donni Juni Priansa. (2011). Manajemen SDM dalam Organisasi Publik dan Bisnis. Bandung. Alfabeta.

Sugiono. 2012. Metode Penelitian Manajemen. Alfabeta. Bandung

Simanjuntak dan Calam. 2012. "Pengaruh Kepemimpinan Transformasional dan Motivasi Terhadap Kinerja Karyawan PT. PLN (Persero) Cabang Binjai Wilayah Sumatera Utara”. Dalam Jurnal Sintikom. Volume 11 No. 2 Binjai : STIMIK Triguna Dharma Sumatera Utara

Tintami, Lila. 2012 “Pengaruh Budaya Organisasi dan Gaya Kepemimpinan Transformasional Terhadap Kinerja Karyawan Melalui Displin Kerja pada Karyawan Harian SKT Megawon II PT. Djarum Kudus". Semarang : Diponegoro Journal of Social \&Politic, Tahun 2012, hlm. 1-8 